\title{
PERANAN CUEPACS TERHADAP TUNTUTAN KENAIKAN GAJI ANGGOTA PERKHIDMATAN AWAM DI PERSEKUTUAN TANAH MELAYU, 1957-1970 ${ }^{1}$ The role of CUEPACS against Claims for Wages Increase in Civil Servant of the Federation of Malaya, 1957-1970
}

\author{
${ }^{1}$ SHARIFAH DARMIA BINTI SHARIF ADAM \\ ${ }^{2}$ AHMAD KAMAL ARIFFIN BIN MOHD RUS \\ ${ }^{I}$ Pusat Penataran Ilmu dan Bahasa, Universiti Malaysia Sabah, Jalan UMS, 88400 Kota Kinabalu \\ ${ }_{2}^{2} J a b a t a n$ Sejarah, Fakulti Sastera dan Sains Sosial, Universiti Malaya \\ ${ }^{1}$ shdarmia@ums.edu.my, 2akamal@um.edu.my \\ Dihantar: 3 Ogos 2018 / Diterima: 29 Mac 2019
}

\begin{abstract}
Abstrak Artikel ini membincangkan peranan Kongres Kesatuan PekerjaPekerja dalam Perkhidmatan Awam (Congress of Union of Employees in the Public Services - CUEPACS) dalam usahanya menuntut kenaikan gaji bagi anggota perkhidmatan awam di Persekutuan Tanah Melayu (PTM) dalam tempoh antara tahun 1957 hingga 1970. Pada tahun 1957, PTM mencapai kemerdekaan dan serentak dengan itu pentadbiran PTM beralih daripada kerajaan kolonial British kepada kerajaan PTM sendiri. Perkhidmatan awam turut mengalami pelbagai perubahan. Namun, gaji yang diterima oleh anggota perkhidmatan awam didapati tiada perubahan. Anggota perkhidmatan awam yang berkhidmat selepas merdeka masih menerima gaji yang sama ketika mereka berada di bawah pentadbiran kerajaan kolonial British. Walau bagaimanapun, peningkatan taraf hidup penduduk selepas merdeka telah memberi kesan terhadap anggota perkhidmatan awam kerana peningkatan tersebut tidak selaras dengan jumlah gaji mereka. Pada masa yang sama, kajian ini turut menyentuh peranan CUEPACS mewujudkan persamaan gaji antara anggota wanita dan lelaki dalam perkhidmatan awam. Oleh itu, fokus utama dalam perbincangan ini adalah untuk mengenal pasti tindakan CUEPACS menuntut kenaikan gaji bagi anggota perkhidmatan awam dan persamaan gaji anggota wanita dan lelaki. Kajian ini juga menilai sejauh mana kerjasama antara CUEPACS dan kerajaan PTM dalam usaha meningkatkan kadar gaji anggota perkhidmatan awam di PTM. Maklumat tentang peranan CUEPACS dalam usaha meningkatkan kenaikan dan persamaan gaji anggota perkhidmatan awam di PTM diperoleh daripada Laporan Tahunan CUEPACS, Parliamentary Debate, Pekeliling
\end{abstract}


Perkhidmatan, laporan surat khabar dan penulisan buku. Hasil kajian mendapati bahawa peranan CUEPACS dalam tuntutan kenaikan gaji bukan sahaja telah membolehkan anggota perkhidmatan awam di PTM menikmati kenaikan gaji tetapi juga membolehkan anggota perkhidmatan awam wanita dan lelaki mendapat persamaan gaji.

Kata kunci: CUEPACS, tuntutan kenaikan gaji, anggota perkhidmatan awam, taraf hidup, persamaan gaji.

Abstract This article discusses the role of the Congress of Unions of Employees in the Public Services (CUEPACS) in an effort to raise wages for civil servant in the Federation of Malaya (FM) between 1957 until 1970. In 1957, FM achieved independence and simultaneously, the FM administration shifted from the British colonial government to the FM government. In line with that, the public service has undergone various changes. However, in terms of wages received by civil servant, no changes were made. This is because civil servant who have served after independence still receive the same wages when they are under the administration of the British colonial government. However, the increase in the standard of living after the independence has affected the civil servant as the increase is not in line with their wages. At the same time, the study also touches on the role of CUEPACS to create wage equality between women and men in the civil service. Hence, the main focus of the discussion is to identify what CUEPACS's action is to demand wages increase for civil servants and wages equality between women and men. In addition, this study also assesses the extent of the collaboration between CUEPACS and the FM government in the effort to increase the wages of civil servant in FM. Information on the role of CUEPACS in the effort to improve the wages increase and wages equality of civil servant in FM is derived from CUEPACS Annual Report, Parliamentary Debate, Service Circulars, newspaper report and book writing. The findings show that the role of CUEPACS in wages raising claims has not only allowed civil servant at FM to enjoy wage increases but also allow civil servant among women and men to get payroll similarities.

Keywords: CUEPACS, pay rise claims, civil servant, living standards, wages equality. 


\section{PENGENALAN}

Anggota perkhidmatan awam merupakan agen penting dalam menasihati dan melaksanakan dasar-dasar kerajaan terhadap pembangunan kerajaan. Hal ini bermakna, kejayaan atau kegagalan pelaksanaan segala program pembangunan yang dirancang oleh kerajaan bergantung sepenuhnya kepada kecekapan anggota perkhidmatan awamnya dalam menjalankan urusan pentadbiran. Oleh itu, penubuhan persatuan atau kesatuan sekerja adalah penting, bukan sahaja untuk mewakili anggota perkhidmatan awam tetapi juga sebagai platform dalam memastikan hak dan keadilan anggota perkhidmatan awam di PTM terus terpelihara. Sebelum perbincangan lanjut, perlu dijelaskan bahawa persoalan tentang hal kenaikan gaji bagi anggota perkhidmatan awam telah pun dikemukakan sejak sebelum merdeka lagi oleh dua persatuan sekerja. Persatuan sekerja tersebut adalah Kongres Kesatuan Sekerja Malaya (Malayan Trade Union Council - MTUC) dan Majlis Kebangsaan Whitley. Hasil usaha kedua-dua persatuan ini, berlaku perubahan, iaitu peningkatan gaji bagi anggota perkhidmatan awam di PTM. Kemudian, selepas mencapai kemerdekaan pada tahun 1957, isu berhubung kenaikan gaji ini telah dikemukakan oleh dua kesatuan sekerja, iaitu Kongres Kesatuan Pekerja-pekerja dalam Perkhidmatan Awam (Congress of Union of Employees in the Public Service - CUEPACS) dan Majlis Kebangsaan Pertubuhan Wanita (National Council of Women's Organisation - NCWO). Namun begitu, perbincangan dalam kajian ini hanya akan difokuskan terhadap peranan CUEPACS dalam menuntut kenaikan gaji bagi anggota perkhidmatan awam di PTM antara tahun 1957 hingga 1970.

\section{LATAR BELAKANG PENUBUHAN KONGRES KESATUAN PEKERJA-PEKERJA DALAM PERKHIDMATAN AWAM (CONGRESS OF UNION OF EMPLOYEES IN THE PUBLIC SERVICE - CUEPACS)}

Selepas mencapai kemerdekaan ${ }^{2}$ dan berada di bawah pentadbiran kerajaan Persekutuan Tanah Melayu (PTM), Kongres Kesatuan Pekerja-Pekerja dalam Perkhidmatan Awam (Congress of Union of Employees in the Public Services - CUEPACS) merupakan satu kesatuan sekerja yang sangat 
signifikan dan telah memberikan sumbangan besar terhadap usaha untuk menuntut kenaikan gaji bagi anggota perkhidmatan awam di PTM. ${ }^{3}$ Bagi memahami peranan CUEPACS terhadap tuntutan kenaikan gaji anggota perkhidmatan awam di PTM, penjelasan tentang latar belakang kesatuan sekerja tersebut perlu dihuraikan. Pada 23 Oktober 1957, kerajaan PTM telah bertindak memberi kebenaran untuk penubuhan CUEPACS. ${ }^{4}$ Dengan itu, CUEPACS telah diberikan sijil pendaftaran sebagai Persekutuan Kesatuan Sekerja di bawah Enakmen Kesatuan Sekerja bagi membolehkannya sah di sisi undang-undang dan dapat memainkan peranannya. ${ }^{5}$

CUEPACS diberikan status sebagai sebuah kesatuan sekerja dengan mudah kerana mendapat sokongan kuat anggota perkhidmatan awam terhadap kerajaan PTM pada ketika itu, di samping mengambil kira keahlian CUEPACS yang terdiri daripada anggota perkhidmatan awam sahaja. Berhubung pemberian mudah status sebagai sebuah kesatuan sekerja tersebut, kajian mendapati sejak tahun 1940-an semasa pihak komunis mendominasi kepimpinan kesatuan sekerja di PTM, kesatuan sekerja dalam sektor kerajaan merupakan satu-satunya kesatuan sekerja yang bebas daripada pengaruh komunis (Rohana Ariffin, 1997: 127). Setelah mencapai kemerdekaan, kerajaan PTM mengambil keputusan untuk membolehkan CUEPACS menjadi sebuah kesatuan sekerja yang berdaftar dan sah di sisi undang-undang. Selain itu, barisan pemimpin CUEPACS juga didapati daripada kalangan mereka yang mendapat pendidikan Inggeris di bandar dan merupakan anggota dalam birokrasi kerajaan. Walaupun sejumlah besar ahli CUEPACS terdiri daripada pekerja dalam perkhidmatan kumpulan perindustrian dan manual (The Industrial and Manual Group - I.M.G.), golongan tersebut tidak memberikan kesan yang besar terhadap kepimpinan dalam CUEPACS. Kesemua hal ini turut menjadi asas kepada pemberian status sebagai sebuah kesatuan sekerja yang mudah kepada CUEPACS. Di samping itu, tindakan kerajaan PTM juga boleh dikaitkan dengan pengumuman polisinya terhadap kesatuan sekerja, iaitu memberi sokongan kepada pergerakan sekerja yang bersifat demokratik dan bebas di PTM. ${ }^{6}$ Senario ini menunjukkan bahawa bahawa pihak kerajaan PTM memberi sokongan terhadap penubuhan CUEPACS sebagai sebuah kesatuan sekerja yang khusus untuk semua anggota perkhidmatan awam dan kesatuan sekerja sektor awam di PTM. Walau bagaimanapun, kerajaan PTM juga melihat penubuhan CUEPACS sebagai sebuah kesatuan sekerja yang 
menjadi perantara bagi anggota perkhidmatan awam dengan kerajaan PTM untuk berbincang tentang pelbagai masalah tanpa mengganggu kepimpinan kerajaan (Rohana Ariffin, 1997: 127).

Sungguhpun CUEPACS telah ditubuhkan sejak tahun 1957 lagi tetapi konvensyen pertama CUEPACS diadakan pada 6 September 1959. Kemudian, pada 12 November 1960 CUEPACS telah didaftarkan semula di bawah Ordinan Kesatuan Sekerja 1959 (No. Daftar: 195) ekoran penyusunan semula Pejabat Pendaftar Kesatuan Sekerja. Apa yang menariknya tentang CUEPACS dapat dilihat melalui keahliannya yang merangkumi semua anggota perkhidmatan awam tanpa mengambil kira gred atau pangkat kakitangan terbabit (Yap Sui Fok, 1998/89: 18). Bermakna, CUEPACS dianggotai oleh semua anggota perkhidmatan awam daripada pelbagai gred dan pangkat di PTM. Selain itu, keanggotaan CUEPACS juga turut terbuka kepada semua kesatuan sekerja dalam perkhidmatan awam yang berdaftar sama ada di Semenanjung Malaysia, Sabah atau Sarawak. Walaupun demikian, setiap kesatuan sekerja berdaftar yang ingin menjadi anggota dalam CUEPACS dikehendaki memberi notis kepada ahli-ahlinya 14 hari sebelum mesyuarat agung meluluskan satu ketetapan dalam persidangan perwakilan atau mesyuarat agung berkenaan persetujuan kesatuan sekerja tersebut untuk menganggotai CUEPACS. Tindakan seterusnya adalah kesatuan sekerja berkenaan perlu menghantar permohonan kepada Setiausaha Agung CUEPACS untuk dibentangkan dalam Mesyuarat Majlis Kongres. Majlis Kongres atau badan yang diberi kuasa pula bebas menerima atau menolak kesatuan terbabit untuk bergabung tanpa memberi apa-apa sebab atas penolakan tersebut. Namun, permohonan kesatuan yang dipersetujui oleh Majlis Kongres atau badan yang diberi kuasa akan dikemukakan kepada Ketua Pengarah Kesatuan Sekerja untuk didaftarkan di bawah CUEPACS. Bagaimanapun, bagi kesatuan sekerja Badan Berkanun atau Pihak Berkuasa Tempatan (PBT), ia memerlukan kelulusan Yang Berhormat Menteri Sumber Manusia terlebih dahulu sebelum diterima menjadi anggota dalam CUEPACS. Sementara itu, berhubung jumlah ahli CUEPACS didapati dari semasa ke semasa telah berkurangan berbanding pada awal penubuhan CUEPACS. Banyak jabatan atau agensi kerajaan telah diswastakan dan anggotanya tidak lagi layak untuk terus berada dalam CUEPACS sebalik mereka akan menyertai MTUC. ${ }^{7}$ 
Dari segi struktur organisasi CUEPACS pula memperlihatkan Dewan Kongres sebagai badan tertinggi dengan ahlinya terdiri daripada presiden, timbalan presiden, 11 wakil presiden, setiausaha umum, 2 timbalan setiausaha umum, pembantu setiausaha umum, 11 pembantu setiausaha, setiausaha kewangan, timbalan setiausaha kewangan dan satu wakil daripada setiap kesatuan dan bahagian (Rohana Ariffin, 1997: 131). Jumlah wakil yang ramai daripada pelbagai kesatuan sekerja dan bahagian menyebabkan jumlah perwakilan dalam dewan tidak tetap dan berubah dari semasa ke semasa dengan kebiasaannya melebihi 30 orang. Di bawah Dewan Kongres ini pula terdapat pelbagai jawatankuasa, iaitu eksekutif viz-a-viz, gred dan komiti jabatan. Beberapa biro dibentuk untuk melaksanakan pelbagai bidang pekerjaan, iaitu pendidikan, pembayaran dan perkhidmatan, penerbitan dan maklumat, perancangan dan penyelidikan, perumahan, kesihatan dan keselamatan, sosial, ekonomi, politik alam sekitar dan pelanggan. ${ }^{8}$ Oleh itu, jelaslah ditunjukkan bahawa CUEPACS adalah sebuah kesatuan sekerja yang tersusun dan cekap.

Perbincangan tentang peranan CUEPACS dalam usaha menuntut kenaikan gaji bagi anggota perkhidmatan awam di PTM akan lebih difahami selepas tinjauan terhadap objektif penubuhannya. CUEPACS ditubuhkan dengan objektif seperti berikut:

a. Membuat apa-apa yang perlu untuk menggalakkan kepentingan atau untuk kesempurnaan kerja-kerja semua atau mana-mana kesatuan sekerja gabungannya.

b. Melindungi kepentingan kesatuan-kesatuan sekerja gabungan dan anggota-anggotanya.

c. Berusaha memperbaiki keadaan-keadaan kerja misalnya pengambilan, masa kerja, kenaikan pangkat, tatatertib, keselamatan jawatan, gaji dan faedah-faedah persaraan anggota-anggota kesatuan sekerja gabungan.

d. Mengatur perhubungan pekerja atau majikan sepanjang yang mengenai perhubungan di antara Kerajaan dengan mana-mana anggota Kesatuan Anggota.

e. Berusaha menubuhkan jentera yang dipersetujui di antara majikan dengan CUEPACS bagi maksud merunding dan membincangkan 
segala perkara mengenai kesatuan-kesatuan sekerja anggota dan anggota-anggotanya.

f. Mengadakan faedah-faedah bagi anggota-anggota kesatuan sekerja anggota sebagaimana yang akan diputuskan oleh Konvensyen Kongres.

g. Berusaha membantu (secara kewangan atau lain-lain) semua atau mana-mana kesatuan sekerja anggota dan anggota-anggotanya.

h. Membantu mana-mana kesatuan sekerja anggota atau manamana anggotanya sama ada secara kewangan atau lain-lain untuk memperoleh apa-apa nasihat undang-undang tertakluk kepada perbekalan-perbekalan dalam Undang-undang Kesatuan Sekerja yang berkuatkuasa.

i. Menggalakkan undang-undang mengenai kepentingan kesatuankesatuan anggota khasnya atau kesatuan-kesatuan sekerja amnya.

j. Menjalankan, jika diputuskan oleh Konvensyen Kongres, kerjakerja mengarang, mencetak, menerbit dan mengedarkan apa-apa akhbar, majalah, sari berita atau lain-lain persuratan bercetak untuk memajukan tujuan-tujuan CUEPACS atau menggalakkan kepentingan kesatuan-kesatuan anggotanya.

k. Menggalakkan kebajikan material, sosial dan pelajaran kesatuankesatuan anggota dengan apa-apa cara yang sah yang dianggap patut oleh Konvensyen Kongres atau Majlis Kongres.

1. Amnya menjalankan segala tindakan dan usaha yang perlu untuk memajukan tujuan-tujuan tersebut di atas mengikut keputusankeputusan yang dibuat oleh Kongres dalam Konvensyen Tiga Tahun Sekali atau Konvensyen Khas. ${ }^{9}$

Berdasarkan objektif tersebut, CUEPACS dilihat begitu ketara sebagai kesatuan sekerja yang mengkhusus untuk melaksanakan pembangunan kebajikan anggota perkhidmatan awam dalam PTM. Perkara ini menyebabkan CUEPACS menjadi satu-satunya kesatuan sekerja sektor awam di PTM yang mempunyai pengaruh dalam menentukan kebajikan dan hak bagi anggota perkhidmatan awam.

Setelah dianalisis berkenaan pembangunan kebajikan anggota perkhidmatan awam ini, terdapat beberapa isu kebajikan yang telah 
dikemukakan oleh CUEPACS kepada kerajaan PTM. Antara perkara tersebut adalah kenaikan gaji, memperbaiki syarat-syarat perkhidmatan, kerja lebih masa, waktu rehat, keadaan bekerja dan jenis pekerjaan, suasana persekitaran di tempat kerja, jaminan dari sebarang kemalangan, meningkatkan mutu keselamatan dan juga memberi perhatian dalam aspek kesihatan. Walau bagaimanapun, antara kesemua perkara tersebut didapati tuntutan dan desakan berkenaan kenaikan gaji bagi anggota perkhidmatan awam telah menjadi isu dan mendapat perhatian serius daripada pihak kerajaan PTM.

\section{PERANAN CUEPACS TERHADAP TUNTUTAN KENAIKAN GAJI ANGGOTA PERKHIDMATAN AWAM}

Isu berkenaan kenaikan gaji bagi anggota perkhidmatan awam menjadi aspek yang sering dikemukakan kepada pihak kerajaan PTM sejak mencapai kemerdekaan dan kemudian menjadi begitu jelas pada tahun 1960-an. Dalam hal tersebut, peranan CUEPACS adalah mendesak pihak kerajaan PTM supaya tangga gaji yang diberikan kepada anggota perkhidmatan awam dibuat dengan seadil-adilnya selaras dengan perkembangan dan keperluan semasa. Pada masa yang sama juga, CUEPACS menuntut supaya kadar gaji dan syarat-syarat yang diberikan kepada anggota perkhidmatan awam tidak jauh beza dengan kadar gaji yang dibayar kepada pekerja-pekerja dalam bidang perusahaan. Hal ini demikian kerana CUEPACS mendapati bahawa tiada perubahan dalam jumlah gaji yang diterima oleh anggota perkhidmatan awam sebelum atau selepas PTM mencapai kemerdekaan. Situasi tersebut ternyata tidak berpatutan dengan bebanan kerja yang semakin bertambah bagi anggota perkhidmatan awam, khususnya selepas PTM mencapai kemerdekaan. ${ }^{10}$ Oleh itu, CUEPACS dilihat terfokus pada persoalan berkaitan gaji kerana jumlah gaji yang berpatutan sangat penting untuk memastikan kecekapan anggota dalam perkhidmatan awam terus terjamin.

Sungguhpun begitu, perlu dijelaskan juga bahawa tuntutan kenaikan gaji oleh CUEPACS sebenarnya lebih menjurus terhadap peningkatan jumlah gaji bagi golongan anggota perkhidmatan awam dalam peringkat bawahan, iaitu perkhidmatan Bahagian IV atau golongan pekerja 'kolar biru' yang hanya mempunyai kelayakan akademik di peringkat sekolah 
rendah dan kumpulan pekerja-pekerja buruh kasar yang mendapat bayaran gaji kecil. Tumpuan terhadap anggota dalam bahagian tersebut dibuat dengan mengambil kira kenyataan bahawa anggota bawahan inilah yang menerima kesan paling ketara akibat kenaikan barangan keperluan kerana dengan kadar gaji yang kecil mereka berhadapan dengan kesukaran untuk membeli barangan keperluan. Sebagai tindakan untuk mengatasi masalah tersebut, CUEPACS telah mengemukakan tuntutan kenaikan gaji melalui usul tergempar dalam mesyuarat CUEPACS yang keenam pada 3 hingga 5 Oktober 1964 seperti berikut:

"Mesyuarat Kongres CUEPACS yang keenam bersetuju menyeru kerajaan menguatkuasakan dengan segera tawaran kenaikan sementara sebanyak 50 peratus pada gaji yang ada sekarang pada semua Pegawai Bahagian IV dan kumpulan Pekerja-pekerja Buruh Kasar. Mesyuarat ini juga bersetuju bahawa Jawatan Kuasa Kerja Kongres bersama-sama dengan Bahagian IV dan kumpulan Pekerjapekerja Buruh Kasar mengambil langkah-langkah sewajarnya mengaturkan satu mesyuarat dengan Perdana Menteri bagi mempersetujui soal ini dengan segera." 11

Sebagai tindakan susulan, CUEPACS telah menghantar satu telegram kepada Perdana Menteri PTM, iaitu Tunku Abdul Rahman Putra Al Haj bagi menyatakan hal berkenaan tuntutan kenaikan gaji tersebut. Seterusnya, pada 23 November 1964, Encik V. E. Jesudoss selaku Yang di-Pertua CUEPACS turut bertindak menemui Setiausaha Tetap Jabatan Perdana Menteri. Hasil pertemuan tersebut, Encik Jesudoss telah dimaklumkan bahawa tuntutan CUEPACS akan dibincangkan oleh jemaah menteri dengan kadar segera. ${ }^{12}$ Kemudian, setelah tuntutan tersebut dipertimbangkan oleh kerajaan PTM, satu tawaran telah diberikan pada 28 Januari 1965. Kerajaan menawarkan sebanyak 5 peratus kenaikan kepada gaji pokok yang bermakna kenaikan gaji sekurang-kurangnya $\$ 5.00$ sebulan kepada semua anggota perkhidmatan awam dalam Bahagian IV tetapi tawaran berkenaan ditolak oleh CUEPACS atas alasan tidak memenuhi tuntutan mereka yang mahukan kenaikan jumlah gaji lebih tinggi. Rentetan itu, CUEPACS meminta kerajaan PTM supaya menimbangkan semula tuntutan kenaikan gaji tetapi sekurang-kurangnya sebanyak 10 peratus daripada gaji pokok, iaitu kenaikan gaji sekurangkurangnya sebanyak \$20.00 sebulan kepada semua anggota perkhidmatan awam dalam Bahagian IV dan pekerja-pekerja buruh kasar. 
Oleh itu, pada 6 Februari 1965 CUEPACS telah bertindak menghantar satu perwakilan untuk menemui perdana menteri sekali lagi bagi membincangkan semula tuntutan mereka berhubung kenaikan gaji pokok sebanyak 10 peratus atau $\$ 20.00$ sebulan. Walau bagaimanapun, pada 20 Mac 1965 pihak kerajaan PTM telah membuat kenyataan seperti berikut;

\begin{abstract}
"Didapati bahawa pemberian sekurang-kurangnya $\$ 10.00$ kepada gaji pokok pegawai-pegawai Bahagian IV yang bergaji antara $\$ 71.00$ hingga $\$ 90.00$ sebulan mewakili kenaikan sebanyak lebih 10 peratus yang mana bersama-sama dengan tuntutan pihak pekerja bahawa kenaikan setinggi-tinggi yang boleh haruslah diberikan kepada pegawai-pegawai di luar lingkungan pendapatan gaji rendah". ${ }^{3}$
\end{abstract}

Kenyataan tersebut dengan jelas menunjukkan bahawa kerajaan PTM masih kekal dengan pendirian untuk mempersetujui hanya 5 peratus sahaja kenaikan gaji bagi anggota perkhidmatan awam dalam Bahagian IV. ${ }^{14}$ Kenyataan ini memperlihatkan bahawa CUEPACS tidak berjaya menuntut kenaikan gaji sebanyak 10 peratus. Malahan, tindakan beberapa pertubuhan pekerja dalam Bahagian IV di negeri Perak dan Johor yang telah menerima serta mempersetujui tawaran kerajaan PTM bagi kenaikan sebanyak 5 peratus sahaja kepada gaji pokok dengan sekurang-kurangnya $\$ 10.00$ mengecewakan CUEPACS. Tindakan pertubuhan pekerja itu juga telah menyebabkan percanggahan pendapat dalam kalangan ahli-ahli CUEPACS. Keadaan ini memberi kesempatan kepada pihak kerajaan PTM untuk menegaskan bahawa pihak kerajaan PTM tidak dapat menawarkan kenaikan gaji lebih daripada 5 peratus atau $\$ 10.00$ kepada anggota perkhidmatan awam dalam Bahagian IV. ${ }^{15}$ Kemudian, setelah beberapa perundingan dengan pihak kerajaan menemui kegagalan, akhirnya pada 7 Oktober 1965 CUEPACS terpaksa akur dan menerima tawaran tersebut.

Sementara itu, perlu dijelaskan juga bahawa usul yang dikemukakan oleh CUEPACS berkenaan kenaikan gaji turut merangkumi kumpulan pekerja-pekerja buruh kasar. Hal ini disebabkan kesatuan-kesatuan yang bergabung di bawah CUEPACS meliputi kumpulan pekerja-pekerja buruh kasar yang berjumlah kira-kira 18,000 orang. Mereka tidak diwakili dalam Majlis Whitley Pekerja-pekerja Buruh Kasar. Oleh itu, apabila perwakilan CUEPACS menemui Perdana Menteri pada 16 Februari 1965, Perdana 
Menteri telah menyatakan bahawa tawaran yang serupa, iaitu kenaikan gaji sebanyak 5 peratus turut diberikan kepada kumpulan pekerja-pekerja buruh kasar. ${ }^{16}$ Bermakna, anggota perkhidmatan awam dalam Bahagian IV dan kumpulan pekerja-pekerja buruh kasar akan sama-sama menerima kenaikan gaji yang ditawarkan oleh kerajaan PTM iaitu sebanyak 5 peratus atau $\$ 10.00$ sahaja.

Tuntutan CUEPACS terhadap kenaikan gaji kemudian dapat dilihat apabila kesatuan sekerja tersebut menentang penubuhan sebuah jawatankuasa khas untuk mengkaji semula susunan sistem gaji, sebaliknya CUEPACS mahu sebuah Suruhanjaya DiRaja yang dilantik oleh Yang DiPertuan Agong ditubuhkan. ${ }^{17}$ Walaupun sebabnya tidak dinyatakan dengan jelas, seorang pegawai tinggi CUEPACS telah menyatakan kepada ahkbar Berita Harian bahawa laporan sebuah jawatankuasa khusus berkemungkinan akan 'diperam' oleh kerajaan dan tidak dibentangkan dalam Parlimen. Sebaliknya, hasil penyelidikan Suruhanjaya DiRaja lazimnya dicetak dan dibentangkan dalam Dewan Rakyat. Menurut CUEPACS, kerajaan telah membuat keputusan untuk membentuk sebuah jawatankuasa yang bertugas seperti berikut:

i. Menimbangkan dan membuat cadangan mengenai dasar-dasar yang akan menentukan gaji dan keadaan bekerja dalam perkhidmatan awam kecuali perkhidmatan angkatan bersenjata dan keretapi.

ii. Untuk menimbangkan dan membuat cadangan sama ada sebarang perubahan diperlukan mengenai susunan gaji dalam perkhidmatanperkhidmatan tersebut.

iii. Untuk menimbangkan sejauh manakah elaun sara hidup dalam susunan gaji yang ada sekarang dapat diseragamkan.

iv. Dalam membuat cadangannya, jawatankuasa tersebut mestilah menimbangkan keadaan kewangan dan ekonomi negara. ${ }^{18}$

Jawatankuasa khas ini mesti dianggotai oleh seorang pegawai utama Bank Dunia dan lima lagi adalah Australia atau Britain, India, seorang hakim Mahkamah Tinggi Malaysia, seorang bekas anggota utama perkhidmatan awam Malaya dan seorang yang terkemuka dalam masyarakat. Namun, CUEPACS tidak bersetuju dengan perenggan keempat tentang kewangan 
dan ekonomi negara. CUEPACS berpandangan adalah tidak wajar kerajaan menjadikan hal kewangan dan ekonomi negara sebagai ukuran untuk merombak gaji anggota perkhidmatan awam. Selain itu, CUEPACS juga mahu rombakan gaji dibuat merangkumi keseluruhan perkhidmatan awam yang terkandung dalam bahagian 132 Perlembagaan Persekutuan. ${ }^{19}$

Seterusnya, peranan dan sumbangan CUEPACS dalam soal tuntutan kenaikan gaji dapat dilihat melalui isu berhubung Laporan Suruhanjaya Gaji Suffian yang diketuai oleh Tan Sri Hakim Suffian pada tahun 1967. Menerusi Laporan Suruhanjaya Gaji Suffian, CUEPACS meletakkan harapan supaya terdapat perubahan dalam soal memperbaiki taraf gaji anggota perkhidmatan awam Laporan Gaji Suffian merupakan laporan mengenai semakan gaji dan syarat-syarat perkhidmatan anggota perkhidmatan awam di negara ini dan dipengerusikan oleh Tan Sri Hakim Mohd Suffian. Ia merupakan suruhanjaya pertama ditubuhkan untuk membuat semakan berhubung gaji anggota perkhidmatan awam selepas PTM mencapai kemerdekaan.

Ketika itu, harapan CUEPACS untuk mendapatkan keadilan dalam soal gaji telah mendapat perhatian daripada Perdana Menteri. Hal ini terbukti melalui ucapan yang disampaikan oleh Setiausaha Agung CUEPACS, iaitu Jamaluddin bin Mohd. Isa pada tahun 1968 yang menyatakan ucapan tahniah dan doa kepada Tunku Abdul Rahman Putra Al-Haj selaku Perdana Menteri ketika itu kerana bertimbang rasa terhadap masalah kebajikan pekerja dan berusaha untuk memperbaiki nasib anggota perkhidmatan awam di negara ini. Satu lagi tanda keprihatinan kerajaan terhadap kebajikan anggota perkhidmatan awam dalam aspek kenaikan gaji adalah melalui tindakan Perdana Menteri menyerahkan Laporan Suruhanjaya Gaji Suffian kepada CUEPACS dan Majlis Whitley untuk dikaji serentak dengan pegawaipegawai kerajaan, sekali gus telah berjaya meredakan ketegangan yang hampir tercetus akibat kelambatan kerajaan mengeluarkan laporan tersebut. ${ }^{20}$

Setelah Suruhanjaya Gaji Suffian ditubuhkan, ia telah mengumpul keterangan lisan daripada kesatuan-kesatuan sekerja dan pihak majikan selama 36 hari bermula pada 3 Oktober 1966 hingga 7 November 1966. Suruhanjaya Gaji Suffian mendapat sokongan daripada Majlis 
Whitley Kebangsaan (Bahagian I-IV) yang telah menyediakan tambahan memorandum kertas kerja sebanyak 114 naskhah mengandungi semua aspek dan butir perjawatan yang lengkap dan betul. ${ }^{21}$ Selain itu, terdapat juga sebanyak 712 tuntutan diterima daripada orang perseorangan dan pertubuhan pekerja. ${ }^{22}$ Kerjasama dan sokongan daripada pelbagai pihak tersebut menunjukkan bahawa anggota perkhidmatan awam dan badanbadan berkanun berharap agar laporan suruhanjaya tersebut memberikan hasil yang positif khususnya dalam aspek yang melibatkan kenaikan gaji bagi anggota perkhidmatan awam di PTM.

Namun demikian, timbul kegusaran dalam kalangan anggota perkhidmatan awam di PTM apabila Laporan Gaji Suffian tidak dikeluarkan untuk maklumat umum. Hal ini menyebabkan CUEPACS bertindak mengadakan satu persidangan khas yang pertama pada 20 Julai 1967 seterusnya berhasil mendapat mandat untuk mengadakan tindakan perusahaan atau mogok. Berikutan itu, kerajaan PTM bersetuju memberikan beberapa salinan Laporan Gaji Suffian kepada anggota perkhidmatan awam untuk dikaji dan mendapat tindak balas. Selain itu, untuk mengkaji keseluruhan Laporan Gaji Suffian, satu jawatankuasa telah dilantik yang mana pendapatnya diakui oleh semua ahli Majlis Whitley Kebangsaan dan pendapat tersebut telah dibincangkan dengan penuh teliti oleh Jumaah Jawatankuasa Tertinggi CUEPACS pada 30 Ogos $1968 .{ }^{23}$ Hasil perbincangan tersebut juga, jawatankuasa telah memutuskan untuk mengarahkan kesatuankesatuan yang bergabung dengan mereka supaya tidak mengambil tindakan perusahaan atau mogok. Seterusnya, berkenaan dengan hasil kajian dan tindak balas anggota perkhidmatan awam terhadap Laporan Gaji Suffian dapat dilihat melalui dua naskhah tebal mengandungi cadangan dan ulasan oleh pihak anggota perkhidmatan awam yang telah diserahkan kepada Tan Sri Tunku Mohamad selaku Ketua Setiausaha Kerajaan berserta surat kepada Perdana Menteri. ${ }^{24}$ Kandungan surat tersebut menyatakan bahawa Encik T. Narendran, pengerusi Majlis Whitley Kebangsaan Pihak Pekerja juga merupakan Yang Di Pertua CUEPACS menyampaikan ucapan terima kasih daripada pihak pekerja kepada Perdana Menteri kerana memberikan salinan Laporan Suruhanjaya Gaji Suffian kepada anggota perkhidmatan awam sebelum dikeluarkan kepada orang ramai. 
Walau bagaimanapun, kerajaan PTM tidak mengeluarkan Laporan Suruhanjaya Gaji Suffian kepada orang ramai. Kelewatan kerajaan PTM mengeluarkan laporan tersebut sekali lagi menyebabkan CUEPACS bertindak mengadakan satu mesyuarat khas Jumaah Jawatankuasa Tertinggi untuk membincangkan langkah yang diambil bagi mengatasi masalah tersebut. Mesyuarat berkenaan telah diadakan pada 13 Mei 1968 dan keputusan mesyuarat adalah seperti berikut:

(a) Meminta kerajaan supaya memulakan perundingan dengan segera dalam tempoh dua minggu daripada tarikh mesyuarat untuk menyelesaikan masalah-masalah dan mendapatkan penyelesaian kepada perundingan tersebut dalam masa tiga bulan daripada tarikh dimulakan perundingan.

(b) Kesatuan-kesatuan yang bergabung dalam CUEPACS juga diarahkan supaya memanggil dengan segera mesyuarat jawatankuasa kerja masing-masing bagi merangka tindakan yang akan diambil termasuk tindakan mogok dan melaporkan keputusan itu kepada badan pemerintah CUEPACS semasa persidangan perwakilan kongres yang akan diadakan pada penghujung satu bulan dari tarikh mesyuarat ini. ${ }^{25}$

Keputusan yang dibuat oleh Jumaah Jawatankuasa Tertinggi CUEPACS dalam mesyuarat tersebut kemudiannya telah disampaikan kepada kerajaan PTM pada 25 Mei 1968. Berikutan itu, Tan Sri Tunku Mohamad bin Tunku Besar Burhanuddin telah mengadakan mesyuarat dengan pegawai pihak pekerja dan Majlis I.M.G. ${ }^{26}$ Dalam mesyuarat tersebut, wakil-wakil kerajaan telah bertungkus lumus menjelaskan punca kelewatan Laporan Suruhanjaya Gaji Suffian dikeluarkan kepada orang ramai. Menurut wakil-wakil kerajaan tersebut, pelaksanaan Laporan Suruhanjaya Gaji Suffian menyebabkan kerajaan PTM mengeluarkan kos perbelanjaan sebanyak RM96.7 juta. Kos perbelanjaan yang besar inilah yang mempengaruhi kelewatan kerajaan PTM untuk mengeluarkan Laporan Suruhanjaya Suffian kepada orang ramai. Sementara itu, wakil-wakil bagi pihak anggota perkhidmatan awam pula mengutarakan rasa kecewa mereka terhadap sikap dan cara kerajaan PTM mengendalikan hal tersebut dan memohon supaya kerajaan PTM tidak mengisytiharkan keputusan laporan tersebut sehinggalah pertubuhan pekerja dapat mengkaji semula laporan 
berkenaan dan permohonan tersebut telah disampaikan oleh Tan Sri Tunku Mohamad kepada Perdana Menteri. ${ }^{27}$

Seterusnya, pada 23 Jun 1968, satu persidangan Perwakilan Khas CUEPACS telah diadakan. ${ }^{28}$ Persidangan tersebut dihadiri oleh ratusan perwakilan daripada semua kesatuan sekerja yang datang dari seluruh pelosok PTM untuk berhimpun di Dewan Mara, Kuala Lumpur. Dalam persidangan tersebut, anggota perkhidmatan awam telah meluahkan rasa kecewa terhadap keadaan hidup mereka yang terpaksa menerima gaji di bawah garis kemiskinan. Oleh itu, mereka mendesak supaya keputusan dan hasil Laporan Suruhanjaya Gaji Suffian dapat diketahui segera dengan harapan yang tinggi bahawa laporan tersebut dapat membawa perubahan dalam memperbaiki taraf ekonomi mereka (Berita Harian, 11 Julai 1968). Namun, sekali lagi kelewatan pihak kerajaan PTM menunaikan janji untuk mempercepatkan pengeluaran hasil laporan tersebut telah menyebabkan anggota perkhidmatan awam yang dipimpin oleh CUEPACS telah membuat keputusan tegas, iaitu mengadakan tindakan mogok bermula pada tengah malam 1 September $1968 .{ }^{29}$ Berkenaan tindakan mogok tersebut, CUEPACS sebenarnya telah mengarahkan kesatuan-kesatuan sekerja yang bergabung di bawahnya mengeluarkan undi-undi sulit untuk mengadakan tindakan mogok. Kemudian, tindakan mogok dibuat selepas semua kesatuan berkaitan sebulat suara untuk mengambil tindakan tersebut. Berdasarkan penelitian, sebelum itu terdapat beberapa tindakan mogok yang dilakukan oleh beberapa kesatuan sekerja yang berada di bawah CUEPACS. Sebagai contoh tindakan mogok yang berlangsung selama tiga hari oleh pekerja pejabat pos pada bulan Ogos 1964, tindakan mogok oleh pekerja perhutanan pada bulan September $1965^{30}$ yang berlangsung selama 36 hari dan mogok yang dilakukan oleh pekerja perkhidmatan kereta api pada bulan Disember 1967 yang berlangsung selama 33 hari (Rohana Ariffin, 1997: 129). Perkara tersebut menunjukkan bahawa sudah terdapat kesatuan-kesatuan kecil yang sudah mengambil tindakan mogok telah mempengaruhi kesatuan-kesatuan sekerja lain dalam CUEPACS untuk mengambil tindakan yang sama.

Walau bagaimanapun, secara keseluruhannya keputusan CUEPACS mengambil tindakan mogok untuk menuntut kenaikan gaji buat pertama kalinya diadakan pada bulan September 1968 dengan mengemukakan beberapa tuntutan seperti berikut agar; 
a) melaksanakan dengan segera Skim Gaji yang disokong oleh Suruhanjaya Suffian untuk Pekerja-pekerja Bahagian IV, buruh kasar dan bekas buruh gaji hari.

b) Segera memberi kepada bekas buruh gaji hari, yang ada di dalam perkhidmatan sebelum tahun 1952 faedah-faedah bersara yang sangat-sangat menjadi hak mereka selepas pemindahan dari kadar gaji hari kepada kadar gaji bulan mengikut Peraturan 21 Undangundang Pension 1957.

c) Mengisytiharkan Skim Memiliki Rumah sebagaimana yang telah disuarakan oleh kerajaan dalam tahun 1965, yang mana berasal dari dalam tuntutan kita berkehendakkan skim serupa itu dalam tempoh 1954, tetapi ditangguhkan lagi oleh kerajaan dengan sebab-sebab yang tidak diberitahu dan supaya segera merundingkan skim itu didalam Majlis Whitley Kebangsaan dengan tujuan bagi melaksanakannya dengan tidak lengah-lengah lagi.

d) Memulakan perundingan-perundingan segera bagi menyelaraskan gaji-gaji Bahagian I, II dan III yang kenaikan gaji mereka telah tertahan kerana penubuhan Suruhanjaya Gaji dengan tujuan untuk memberi kepada pekerja-pekerja itu gaji yang sesuai dengan tugas dan tanggungjawab mereka serta dengan tarikh kebelakangan.

e) Melaksanakan tawaran gaji sama yang telah diterima; kegagalan melaksanakannya. Kesatuan ini akan mengambil tindakan perusahaan dengan tujuan untuk mendapatkan gaji sama untuk kerja yang sama sebagaimana dalam tuntutan permulaan (Suara CUEPACS, 1968: 10).

Setelah keputusan sebulat suara untuk menjalankan tindakan mogok dicapai, Jawatankuasa Bertindak telah ditubuhkan (Rohana Ariffin, 1997: 129). Selaras dengan itu, satu bilik gerakan telah ditubuhkan di ibu pejabat CUEPACS sebagai pusat gerakan untuk kesatuan-kesatuan yang bergabung di bawahnya mengatur langkah dan persiapan untuk mogok tersebut. Pada masa itu, Encik Yahaya bin Mohamad Ali sebagai Timbalan Yang Dipertua CUEPACS telah dilantik menjadi pengarah pusat gerakan. Melalui tindakan mogok, CUEPACS telah mengadakan rapat umum di seluruh pelusuk negeri di PTM (Suara CUEPACS, 1968: 10). Sementara itu, ahli Jawatankuasa Bertindak pula telah pergi ke merata-rata tempat di PTM untuk memberi keterangan kepada ahli-ahli kesatuan berhubung dengan isu yang timbul antara pihak anggota perkhidmatan awam dengan pihak kerajaan PTM. 
Para pemimpin CUEPACS telah berusaha sedaya upaya menjelaskan kepada semua anggota perkhidmatan awam di PTM berkenaan hak-hak mereka sebagai pekerja. Malahan, terdapat banyak ucapan penuh semangat yang dibuat oleh pemimpin CUEPACS untuk memberi kesedaran kepada anggota perkhidmatan awam supaya memberikan sokongan kepada CUEPACS menuntut penambahbaikan dalam aspek kebajikan dan mendapat keadilan daripada pihak kerajaan PTM. Antara kesatuan yang menyatakan akan turut serta dalam mogok bersama CUEPACS pada 1 September 1968 tersebut adalah Kesatuan Kebangsaan Guru-guru, ${ }^{31}$ manakala Kesatuan Kebangsaan Pekerja Talikom di seluruh Malaysia Barat hanya mengancam untuk mengadakan mogok. ${ }^{32}$ Terdapat juga kesatuan sekerja yang tidak bersetuju menyertai mogok tersebut seperti Kesatuan Kebangsaan Pekerja-pekerja Majlis Bandaran Tempatan Johor. ${ }^{33}$ Keadaan ini memperlihatkan bahawa terdapat sebahagian kesatuan sekerja di bawah CUEPACS bersetuju dan sebahagian lagi tidak bersetuju untuk mengadakan tindakan mogok bagi menuntut kenaikan gaji bagi anggota perkhidmatan awam pada 1 September 1968.

Walaupun CUEPACS mengambil tindakan untuk mengadakan mogok tetapi pihak kerajaan PTM masih berusaha mencari jalan penyelesaian secara aman. Bahkan, tindakan kerajaan PTM untuk meredakan mogok tersebut juga dapat dilihat melalui penubuhan satu Jawatankuasa Bersama. Oleh itu, pada 10 Julai 1968, Tun Abdul Razak yang memegang jawatan sebagai Timbalan Perdana Menteri bersama dengan menteri-menteri lain telah mengadakan perjumpaan dengan wakil-wakil pekerja bertempat di Bilik Gerakan Kerajaan. ${ }^{34}$ Dalam mesyuarat tersebut, satu kata sepakat telah dicapai sehingga membawa kepada termeterainya satu perjanjian. Berhubung dengan perjanjian tersebut, sebenarnya Tun Abdul Razak telah pun mengarahkan pegawai-pegawai kerajaan untuk merangka satu perjanjian yang boleh diterima baik oleh pihak anggota perkhidmatan awam mahupun pihak kerajaan PTM.

Selaras dengan itu, pada 13 Julai 1968 satu mesyuarat telah diadakan antara wakil-wakil pihak kerajaan dengan wakil-wakil pihak anggota perkhidmatan awam. Mesyuarat tersebut dipengerusikan oleh Tan Sri Tunku Mohamad bin Tunku Besar Burhanuddin, Ketua Setiausaha Negara yang 
berperanan sebagai orang tengah antara pihak kerajaan PTM dengan pihak anggota perkhidmatan awam. Beliau disertai oleh Pengarah Perjawatan Tan Sri Abdul Kadir bin Shamsuddin dan pegawai-pegawai Perbendaharaan sebagai wakil-wakil daripada pihak kerajaan. ${ }^{35}$ Sementara itu, pihak pekerja pula diwakili oleh Encik T. Narendran yang merupakan pengerusi CUEPACS, Encik Yahaya bin Mohd selaku Timbalan Pengerusi CUEPACS, setiausaha pihak pekerja, pegawai-pegawai tinggi CUEPACS dan Majlis Whitley Kebangsaan serta Encik Ibrahim Mustaffa dan Encik Allah Baskh dari Majlis I.M.G. Seterusnya, pada 22 Julai 1968 perundingan antara pihak kerajaan PTM dengan wakil anggota perkhidmatan awam mencapai kemuncaknya dengan menandatangani satu perjanjian. Perjanjian tersebut menyatakan pekerja-pekerja bahagian bawahan dalam perkhidmatan awam, iaitu kumpulan kakitangan yang berkhidmat dalam Bahagian IV, kumpulan buruh kasar dan bekas buruh gaji hari dalam Perkhidmatan Keretapi Tanah Melayu akan diberikan faedah jawatan tetap dan pencen ${ }^{36}$ yang sebelum ini tidak dapat dinikmati oleh mereka.

Selain itu, terdapat satu lagi faedah dalam perjanjian tersebut, iaitu anggota wanita yang berkhidmat dalam Bahagian IV turut diberikan jumlah gaji yang sama seperti diterima oleh anggota lelaki. Jika diperhalusi ternyata perkara tersebut merupakan satu perubahan positif, sekali gus telah menjadi perintis kepada persamaan kadar bayaran gaji untuk kakitangan wanita di bahagian-bahagian lain dalam perkhidmatan awam. ${ }^{37}$ Dalam masa yang sama, didapati juga anggota yang berkhidmat sebagai 'budak pejabat' menerima faedah paling besar kerana mereka bukan sahaja mendapat Skim Kenaikan Gaji Baru. Malah, mereka tidak lagi terpaksa berhenti kerja apabila usia mereka menjangkau 21 tahun. Bahkan, 'budak pejabat' juga boleh meneruskan pekerjaan dalam jawatan masing-masing dan boleh menjawat jawatan yang lebih tinggi berdasarkan prestasi cemerlang yang ditunjukkan dalam pekerjaan mereka. Selain itu, gelaran 'budak pejabat' tidak lagi diguna dan digantikan dengan nama Pekerja-pekerja Rendah Pejabat. Perubahan ini menunjukkan pihak kerajaan PTM memandang serius berkenaan pembangunan kebajikan kakitangan awam terutamanya yang berkhidmat di peringkat bawahan. Di samping itu, ia juga menunjukkan bahawa pihak kerajaan PTM sebenarnya turut menyedari kesukaran hidup anggota perkhidmatan awam dalam perkhidmatan rendah akibat kenaikan kos sara hidup. 
Selain daripada kesemua faedah yang akan diterima oleh anggota perkhidmatan awam di peringkat bawahan, terdapat syarat-syarat lain yang terkandung dalam perjanjian berkenaan telah turut membawa perubahan yang lebih baik kepada keseluruhan anggota perkhidmatan awam di PTM. Syarat-syarat tersebut ialah pihak kerajaan PTM mengaku dan bersetuju untuk berunding dengan pihak anggota perkhidmatan awam untuk menyelesaikan tuntutan seperti berikut:

(i) Menyelaraskan keganjilan-keganjilan dan tidak sama rata Skim Gaji untuk pekerja-pekerja Bahagian I, II \& III.

(ii) Melaksanakan gaji sama untuk semua pekerja-pekerja wanita mulai dari 1 Ogos 1968 sebagaimana yang ditawarkan kepada pihak pekerja.

(iii) Melaksanakan rancangan memiliki rumah sendiri kepada semua kakitangan perkhidmatan awam. ${ }^{38}$

Berdasarkan penjelasan tersebut, jelaslah bahawa perjanjian yang ditandatangani pada 22 Julai 1968 antara pihak kerajaan PTM dengan anggota perkhidmatan awam merupakan kejayaan terbesar CUEPACS dalam melaksanakan peranannya untuk menuntut kenaikan gaji bagi anggota perkhidmatan awam. Perjanjian tersebut merupakan satu detik bersejarah di PTM kerana ditandatangani dalam suasana yang penuh harmoni dan bertolak ansur. Walaupun Perjanjian Perusahaan tersebut telah memberikan anggota perkhidmatan awam dalam Bahagian IV dan kakitangan I.M.G. satu kenaikan gaji dengan peruntukan sebanyak RM11.7 juta bagi tempoh 1 Ogos 1968 hingga 31 Julai $1969^{39}$ tetapi selepas 9 bulan berlalu dari tarikh perjanjian itu ditandatangani didapati pihak kerajaan PTM masih belum melaksanakan perjanjian tersebut. Keadaan ini sekali lagi telah menimbulkan perasaan kurang senang hati kepada anggota perkhidmatan awam yang sudah lama menantikan perubahan yang lebih baik dalam tangga gaji mereka.

Berikutan itu, pihak kerajaan PTM telah mengemukakan satu cadangan baharu supaya pelaksanaan perjanjian tersebut diubah dan dalam masa yang sama membuat tawaran baharu. Tindakan kerajaan PTM bukan sahaja dilihat sebagai satu cubaan untuk menidakkan hak asasi anggota perkhidmatan awam tetapi sekali gus membatalkan perjanjian tersebut. Hal 
ini telah menyebabkan kakitangan I.M.G. khususnya kerugian RM4.45 juta. Hal ini demikian kerana jika melihat kepada persetujuan awal, kenaikan gaji anggota perkhidmatan awam tersebut yang sepatutnya telah bermula pada 1 Ogos 1968 tetapi telah tertangguh sehingga pada 1 Mei 1969 menyebabkan anggota perkhidmatan awam yang terlibat mengalami kerugian kenaikan gaji selama 9 bulan. ${ }^{40}$ Kegagalan pihak kerajaan PTM melaksanakan perjanjian awal dikaitkan dengan kos perbelanjaan yang besar. Maka, usaha CUEPACS untuk membawa perubahan dan penambahbaikan dalam soal kenaikan gaji bagi anggota perkhidmatan awam terutama dalam perkhidmatan bawahan belum tercapai. Perbincangan dan rundingan antara pihak kerajaan PTM dan pihak pekerja dalam Majlis Whitley Kebangsaan diteruskan dan hasilnya telah membawa kepada pengumuman oleh Tun Abdul Razak bahawa gaji baharu bagi anggota perkhidmatan awam bermula pada 1 Mei 1969. ${ }^{41}$ Sungguhpun ia jelas telah tertangguh daripada perjanjian yang dibuat pada 22 Julai 1968 tetapi CUEPACS terpaksa mengalah dan menerima tawaran kerajaan PTM walaupun timbul rasa kurang puas hati dalam kalangan anggota perkhidmatan awam.

Sementara itu, peranan CUEPACS juga dapat dilihat apabila satu perwakilan CUEPACS telah menemui Tan Sri Kadir bin Shamsuddin yang memegang jawatan Ketua Pegawai Pentadbir Hal Ehwal Perkhidmatan Awam ketika anggota perkhidmatan awam dalam perkhidmatan Bahagian IV sedang menunggu penerbitan surat Pekeliling Perkhidmatan Seri Paduka Baginda berkenaan gaji baharu mereka. Dalam pertemuan tersebut, Tan Sri Kadir telah memberi satu jaminan bahawa 'semuanya akan beres' dalam beberapa hari lagi. Dengan kata lain, penerbitan surat Pekeliling Perkhidmatan Seri Paduka Baginda yang mengandungi kadar gaji baharu bagi anggota perkhidmatan awam di Bahagian IV akan dikeluarkan dalam masa yang singkat. Tidak lama kemudian, Ketua Pengarah Perkhidmatan Awam, iaitu Tan Sri Syed Zahiruddin bin Syed Hassan telah menghantar sepucuk surat kepada CUEPACS menyatakan bahawa "surat Pekeliling Perkhidmatan telah siap dan akan diterbitkan seberapa segera setelah kita mendapat kebenaran daripada pihak berkenaan." ${ }^{42}$ Oleh itu, apabila terbitnya surat pekeliling tersebut, anggota perkhidmatan awam khususnya dalam kumpulan perkhidmatan rendah telah menerima kenaikan gaji. Perkara ini dilihat merupakan satu kejayaan buat CUEPACS dalam usahanya menuntut 
kenaikan gaji bagi anggota perkhidmatan awam, terutama yang berada dalam perkhidmatan bahagian bawahan.

Berdasarkan penelitian dalam kajian ini, didapati bahawa CUEPACS mempunyai cara atau taktik tersendiri dalam usahanya menuntut kenaikan gaji bagi anggota perkhidmatan awam di PTM. Taktik tersebut dapat dilihat dengan jelas melalui tindakannya menyelesaikan semua tuntutan dengan cara perundingan. Sekiranya cara tersebut tidak berkesan, barulah CUEPACS menggunakan cara melalui undang-undang untuk menggesa kerajaan supaya memberikan perhatian serius terhadap kebajikan anggota perkhidmatan awam. Pada masa yang sama, walaupun terdapat ketegangan yang muncul antara pihak CUEPACS dengan pihak kerajaan PTM disebabkan tuntutan kenaikan gaji tetapi CUEPACS sentiasa menggunakan dasar 'soft-line' iaitu mengambil pendekatan penyelesaian melalui perundingan atau perbincangan. Pihak kerajaan PTM juga telah mengambil tindakan yang wajar apabila sentiasa bersedia untuk berunding dengan anggota perkhidmatan awam dan mengambil pendekatan bertolak ansur untuk mencari jalan penyelesaian. Tindakan CUEPACS dalam tuntutan kenaikan gaji bagi anggota perkhidmatan awam di peringkat bawah bukan sahaja telah meningkatkan taraf kebajikan bagi anggota perkhidmatan awam di PTM tetapi dalam masa yang sama berjaya mendorong pihak kerajaan PTM untuk melaksanakan usaha-usaha melalui dasar-dasar kerajaan bagi meningkatkan kadar gaji bagi anggota perkhidmatan awam di PTM.

\section{PERANAN CUEPACS TERHADAP PERSAMAAN GAJI ANTARA ANGGOTA WANITA DAN LELAKI DALAM PERKHIDMATAN AWAM}

Berdasarkan penelitian dalam kajian ini, CUEPACS berperanan penting dalam usaha meningkatkan kadar gaji yang diterima oleh anggota wanita. Dengan kata lain, CUEPACS turut menuntut persamaan gaji antara anggota wanita dengan lelaki dalam perkhidmatan awam. Sebenarnya, persoalan berkenaan gaji antara dua jantina ini telah dibangkitkan sejak tahun 1946 apabila pihak Kerajaan British melantik Trust Commission untuk mengkaji dan membuat cadangan berhubung pembayaran gaji kepada anggota perkhidmatan awam (Rohana Ariffin, 1997: 138). Namun demikian, ketika 
itu hal berkaitan dengan pembayaran gaji kepada anggota wanita tidak disebut dalam laporan tersebut menyebabkan ia sekali lagi dibincangkan dalam Suruhanjaya Benham yang dilaksanakan pada tahun $1950 .{ }^{43}$ Berikutan itu, terdapat syor atau cadangan supaya anggota wanita mendapat gaji yang lebih rendah berbanding anggota lelaki. Hal ini bermaksud bahawa gaji yang diterima oleh anggota wanita adalah sekitar empat perlima daripada gaji yang diterima oleh anggota lelaki. Punca utama diskriminasi ini adalah kerana sesetengah anggota wanita dalam perkhidmatan awam yang tetap berkhidmat dalam pekerjaan mereka selepas berkahwin tidak boleh secara bebas dipindahkan ke satu-satu tempat sebagaimana anggota lelaki. Situasi ini dianggap telah menyukarkan pihak kerajaan PTM mengarahkan anggota wanita dalam perkhidmatan awam untuk berkhidmat di tempat-tempat yang memerlukan perkhidmatan mereka. Namun begitu, terdapat beberapa jenis perkhidmatan yang dikecualikan dan diberikan persamaan gaji seperti jurutaip, stenograf, pegawai perubatan, pegawai undang-undang, arkitek dan journalis. ${ }^{44}$ Perlu juga dinyatakan bahawa dalam tempoh antara tahun 1957 hingga 1967, golongan wanita kebanyakannya berkhidmat dalam bidang perguruan, kejururawatan dan perbidanan dengan jumlah seramai 38,439 orang (Rohana Ariffin, 1997: 139).

Menjelang tahun 1960-an, isu berhubung tuntutan persamaan gaji antara anggota wanita dan lelaki dalam perkhidmatan awam semakin mendapat perhatian kerana jumlah penglibatan golongan wanita dalam sektor awam yang semakin bertambah. Sebagai contohnya, ahli Parlimen Jitra Padang Terap, iaitu Datin Fatimah Haji Hashim telah mengemukakan pertanyaan kepada Tunku Abdul Rahman iaitu Perdana Menteri PTM sama ada kerajaan sudah menerima laporan daripada jawatankuasa yang ditugaskan untuk mengkaji kenaikan gaji anggota wanita sama seperti anggota lelaki dalam perkhidmatan awam. Oleh itu, Tunku menjelaskan bahawa laporan tersebut akan disiapkan dengan kadar segera. ${ }^{45}$ Pada tahun 1964 persoalan persamaan gaji bagi anggota wanita dengan anggota lelaki telahpun dibangkitkan dalam Laporan Suruhanjaya Gaji Suffian. Ketika itu, anggota perkhidmatan awam telah menerima tawaran pihak kerajaan PTM yang menyusun satu skim mengadakan persamaan gaji secara beransur-ansur mengambil tempoh selama tiga tahun bermula pada 1 Januari 1965 dikenali sebagai Cara Kerajaan Singapura. ${ }^{46}$ Namun demikian, selepas bermesyuarat 
dengan Majlis Whitley Kebangsaan pada 19 September 1967, anggota perkhidmatan awam telah mengemukakan satu memorandum bertarikh 20 September 1967 yang menyatakan penerimaan tawaran kerajaan PTM sebagaimana dalam tawaran asalnya iaitu seperti berikut:

(a) Tawaran yang dibuat oleh kerajaan itu berjalan dari 1 Januari 1967.

(b) Pegawai-pegawai wanita yang diambil selepas 31 Disember 1967 akan mengikut tangga gaji lelaki.

(c) Pemindahan gaji mengikut cara yang disampaikan kepada pihak pekerja dalam mesyuarat khusus pada 21 Mac $1966 .{ }^{47}$

Walau bagaimanapun, pelaksanaan tawaran kerajaan PTM tidak dilaksanakan sehinggalah tuntutan tersebut dikaji semula dalam satu mesyuarat bersama yang berakhir dengan menandatangani perjanjian antara pihak kerajaan PTM dengan anggota perkhidmatan awam pada 22 Julai 1968. Menyentuh tentang isi kandungan perjanjian tersebut, pihak kerajaan PTM telah bersetuju untuk mengadakan rundingan dengan anggota perkhidmatan awam bagi membincangkan pelaksanaan persamaan gaji antara anggota lelaki dan wanita dalam perkhidmatan awam mengikut tawaran yang telah dibuat oleh pihak kerajaan, tertakluk kepada pertimbangan terhadap kedudukan kewangan kerajaan.

Hasil tuntutan tersebut, kerajaan PTM telah bersetuju memberikan persamaan gaji antara anggota perkhidmatan awam wanita dengan anggota lelaki mengikut peruntukan Pekeliling Perkhidmatan Bil. 5/69 yang menyatakan bahawa bermula pada 1 Mei 1969, anggota wanita dan guru wanita yang berkhidmat mengikut skim perkhidmatan yang sama dengan anggota lelaki dan guru lelaki akan dipindahkan segera atau secara beransur-ansur ke tangga gaji pegawai lelaki dan guru lelaki. Sementara itu, anggota wanita dan guru wanita yang dilantik sebelum 1 Mei 1969 akan dipindahkan dari tangga gaji mereka pada masa itu kepada tangga gaji baharu tetapi tertakluk kepada syarat-syarat seperti sekatan peperiksaan dan kecekapan. ${ }^{48}$ Dengan kata lain, Laporan Suruhanjaya Gaji Suffian turut mengesyorkan persamaan pembayaran gaji dan pembayaran gaji semasa cuti bersalin selama tiga bulan berpantang bagi anggota wanita. Serentak itu, mulai 1 Mei 1969 pegawai dan guru-guru wanita yang menjawat jawatan 
yang tertakluk di bawah skim perkhidmatan yang sama dengan pegawai dan guru-guru lelaki akan dipindahkan serta-merta atau secara beransur-ansur ke tangga gaji yang sama seperti tangga gaji pegawai dan guru-guru lelaki (Pekeliling Perkhidmatan Bil. 5, 1969).

Dalam bidang pekerjaan sebagai kerani, kebanyakan anggota wanita tidak menepati kelayakan kerana persekolahan dan pendidikan mereka terbantut akibat penaklukan tentera Jepun di Tanah Melayu. Malahan, disebabkan hal pendidikan tersebut kerani wanita dianggap sebagai pekerja sementara sahaja. Oleh itu, CUEPACS dan kesatuan pekerja awam yang lain telah menubuhkan Women's Action Front-WAF untuk memperjuangkan kebajikan dalam soal pembayaran gaji yang sama bagi anggota wanita yang berkhidmat sebagai kerani. ${ }^{49} \mathrm{WAF}$ berperanan penting dalam soal menuntut persamaan gaji antara anggota wanita dan anggota lelaki semasa tunjuk perasaan besar-besaran di Dewan Bahasa dan Pustaka, Kuala Lumpur pada bulan April 1968 (Rohana Ariffin, 1997: 139). Walaupun pihak kerajaan PTM telah bersetuju untuk memberikan gaji yang sama antara anggota tersebut tetapi kerajaan memerlukan tempoh masa selama lima tahun untuk melaksanakannya atas alasan masalah kewangan. Sehubungan itu, Puan Aishah binti Haji Abdul Ghani telah menyatakan pandangannya bahawa tuntutan wanita untuk mendapat keadilan sosial dan ekonomi tidak dipandang serius oleh pihak kerajaan. ${ }^{50}$ Walau bagaimanapun, tekanan berterusan daripada CUEPACS dan kesatuan sekerja yang lain telah membantu mempercepatkan tuntutan tersebut. Akhirnya pada tahun 1970, persamaan pembayaran gaji, status berpencen dan syarat-syarat perkhidmatan yang lain diberikan kepada semua anggota wanita dalam perkhidmatan awam. ${ }^{51}$ Dengan itu, jelas peranan CUEPACS sebagai suara bagi anggota wanita dalam perkhidmatan awam untuk menyampaikan masalah tanpa mengira jantina anggota perkhidmatan awam supaya kerajaan sentiasa peka terhadap kebajikan mereka.

Terdapat satu lagi peranan CUEPACS selain menuntut persamaan gaji antara anggota wanita dan lelaki dalam perkhidmatan awam. Peranan tersebut ialah semakan semula peraturan yang telah dibuat berhubung pekerjaan wanita yang telah berkahwin. Hal ini demikian kerana di bawah Perintah Umum Seksyen 32, anggota wanita yang telah berkahwin diminta 
untuk berhenti daripada pekerjaannya dan selepas itu mereka boleh bekerja sebagai pekerja sementara untuk beberapa bulan (F. R. Bhupalan, 2006: 261). Bagaimanapun, tindakan CUEPACS menyemak semula peraturan tersebut telah menyebabkan mulai tahun 1960, anggota perkhidmatan wanita yang telah disahkan dalam jawatan mereka sebelum berkahwin tidak perlu berhenti kerja walaupun selepas berkahwin (Rohana Ariffin, 1997: 138-139). Perkara ini menunjukkan bahawa CUEPACS berjaya menjalankan peranannya sebagai sebuah kesatuan sekerja yang bukan sahaja sentiasa prihatin terhadap aspek gaji tetapi juga aspek lain bagi keseluruhan anggota perkhidmatan awam di PTM tanpa mengira jantina.

\section{PENUTUP}

Dalam tempoh antara tahun 1957 hingga 1970, CUEPACS berperanan penting memberikan sumbangan besar dalam menuntut kenaikan gaji bagi anggota perkhidmatan awam di PTM. Walaupun CUEPACS mengadakan tindakan mogok untuk mencapai matlamat kenaikan gaji bagi anggota perkhidmatan awam, dalam masa yang sama masih bersifat terbuka untuk mengadakan rundingan dengan pihak kerajaan. Keadaan ini menunjukkan bahawa wujud kerjasama yang baik antara CUEPACS dengan pihak kerajaan PTM untuk melaksanakan kenaikan gaji khususnya dalam perkhidmatan Bahagian IV bagi anggota perkhidmatan awam di PTM. Selain itu, hasil usaha CUEPACS juga turut membolehkan anggota wanita menerima kadar gaji yang sama dengan anggota lelaki dalam perkhidmatan awam di PTM berkuat kuasa mulai tahun 1970. Oleh itu, jelaslah bahawa CUEPACS telah berjaya menjadi kesatuan sekerja yang sangat penting dalam memastikan hak dan keadilan bagi anggota perkhidmatan awam di PTM sentiasa terjamin. 


\section{NOTA}

1 Penulisan ini merupakan sebahagian daripada hasil kajian tesis Sharifah Darmia binti Sharif Adam. Perkembangan Perkhidmatan Awam di Persekutuan Tanah Melayu, 1948-1970, Tesis Doktor Falsafah, Jabatan Sejarah, Fakulti Sastera dan Sains Sosial, Universiti Malaya, 2018.

2 Pada pukul 12.00 tengah malam bendera Union Jack telah diturunkan digantikan dengan bendera Persekutuan Tanah Melayu diikuti laungan merdeka. Pada waktu pagi 31 Ogos 1957, bertempat di Stadium Merdeka Kuala Lumpur, Tunku Abdul Rahman telah melaungkan 'merdeka' kemudian diikuti oleh semua hadirin yang hadir. Tunku Abdul Rahman dilantik sebagai Perdana Menteri Persekutuan Tanah Melayu yang pertama. Penjelasan lanjut sila rujuk Ramlah Adam. 2009, Biografi Tunku Abdul Rahman Putra, Kuala Lumpur: Dewan Bahasa dan Pustaka, hlm. 284-290, Straits Times, 31 Ogos 1957 dan Utusan Melayu, 1 September 1957.

3 CUEPACS merupakan sebuah kesatuan sekerja dalam sektor awam merangkumi badanbadan berkanun dan kuasa-kuasa tempatan. Penubuhannya bermula ketika persidangan perwakilan kelima Majlis Pihak Pekerja Kerajaan yang berlangsung pada 24 April 1955, satu resolusi sebulat suara telah diterima yang membawa lahirnya Kongres Kesatuan Pekerja-pekerja dalam Perkhidmatan Awam atau lebih dikenali dengan nama singkatnya, iaitu CUEPACS. Walaupun jelas bahawa Enakmen Kesatuan Sekerja telah mula diperkenalkan di PTM sejak tahun 1940 tetapi ketika itu tidak ada kesatuan sekerja ditubuhkan khusus untuk anggota perkhidmatan awam. Hanya selepas tamatnya Perang Dunia Kedua barulah didapati para pekerja dalam perkhidmatan awam disusun mengikut status jabatan atau ketukangan masing-masing. Namun, apabila banyak kesatuan sekerja yang berganda atau bertindih walaupun mempunyai bidang dan fungsi yang sama sehingga menyukarkan perjuangan memperbaiki keadaan kebajikan bersama menyebabkan terbitnya kesedaran untuk menubuhkan kesatuan sekerja khusus untuk kakitangan awam. Oleh itu, pada tahun 1948 beberapa orang pemimpin kesatuan-kesatuan sekerja sektor awam telah mengambil langkah pertama bagi menubuhkan suatu badan kebangsaan, iaitu Majlis Kakitangan Perkhidmatan Kerajaan (Government Services Staff Council) yang mewakili 40 badan Kesatuan Sekerja Sektor Awam. Matlamat utama majlis tersebut ditubuhkan ialah untuk menggalakkan kerjasama antara kesatuan tanpa melibatkan diri dalam autonomi individu hal ehwal pentadbiran kesatuan-kesatuan berkenaan, memperjuangkan kepentingan dan kebajikan bersama anggota-anggota yang bergaji bulan daripada kesatuan-kesatuan yang menyertainya. Rentetan perkara tersebut, pada 3 April 1949 Peraturan-peraturan Majlis Kakitangan Perkhidmatan Kerajaan telah diluluskan dalam Persidangan Penaja dan berpejabat di No. 1362, Jalan Kandang Kerbau atau sekarang dikenali sebagai Jalan Padang Belia, Brickfields, Kuala Lumpur. Pada awalnya majlis ini dianggotai oleh lapan buah kesatuan tetapi apabila dibubarkan untuk memberi laluan kepada penubuhan CUEPACS, terdapat sebanyak 48 buah kesatuan telah bergabung di bawah majlis ini. Penubuhan Majlis Kakitangan Perkhidmatan Kerajaan ini telah memberi sumbangan besar dalam hal ehwal kebajikan anggota sektor awam dan juga berperanan penting dalam kejayaan Majlis Kebangsaan Whitley (National Whitley Council). Walau bagaimanapun, pada mulanya majlis ini menghadapi pelbagai kesulitan khususnya ketika memperjuangkan isu-isu yang membabitkan kebajikan bersama serta masalah dalam penyusunan dan menyatupadukan kesatuan-kesatuan sekerja sektor awam. Namun, demi kebaikan dan kebajikan pekerja sektor awam pada masa itu dan masa akan datang 
serta betapa pentingnya kewujudan satu badan unggul, terdapat beberapa usaha diambil untuk menggalakkan semua kesatuan dalam sektor awam disusun di bawah satu badan persekutuan. Perkara inilah yang telah menyebabkan kelulusan resolusi oleh Persidangan Perwakilan Kelima pada 24 April 1955 untuk menubuhkan suatu badan yang lebih berkesan dikenali sebagai CUEPACS. Antara tujuannya ialah untuk menggalakkan semua kesatuan sekerja dalam sektor awam menyertai badan baharu ini tanpa mengira jawatan atau gred perkhidmatan mereka. Penjelasan lanjut sila rujuk, Yap Sui Fok, 'CUEPACS, Keanjalan Upah dan Perundingan Kolektif dalam Perkhidmatan Awam Malaysia', Kertas Projek/ LI, Fakulti Ekonomi, Universiti Kebangsaan Malaysia, 1988/89, hlm. 17.

4 http://www.cuepacs.my/index.php/cuepacs-23/sejarah-cuepacs.html, 7 Mac 2018.

5 Ibid., hlm. 18.

6 Report of Mission from the ILO, The Trade Union Situation in the Federal of Malaya, Geneva, 1962, hlm. 33.

7 Visi CUEPACS ialah kekal sebagai pusat kebangsaan Kesatuan Sekerja Unggul dalam Sektor Awam. Misinya ialah mengekalkan CUEPACS sebagai salah sebuah organisasi yang terbaik dan mampu memperjuangkan kepentingan anggota sektor awam dengan berkesan secara berterusan dan menjadikan CUEPACS sebagai sumber rujukan utama berkaitan hal ehwal pekerja serta pemimpin mengikut dasar kepimpinan berpengalaman (k-leadership). http://www.cuepacs.my/index.php/cuepacs-23/visi-misi-objektif.html, 7 Mac 2018.

8 Ibid.

9 http://www.cuepacs.my/index.php/cuepacs-23/visi-misi-objektif.html, 7 Mac 2018.

${ }^{10}$ Ibid.

${ }^{11}$ CUEPACS Annual Report 1964-1965, $7^{\text {th }}$ Congress Convention, 19, 20 and 21 November 1965, at Selangor Girl Guides' Association Hall, Kuala Lumpur, hlm. 64.

${ }_{12}$ Ibid.

13 Ibid.

14 Tuntutan gaji bagi anggota perkhidmatan awam dalam Bahagian IV telah dilaksanakan oleh kerajaan pada 1 Januari 1965. Pekeliling Perkhidmatan Bil. 23 Tahun 1965, Kuala Lumpur, 31 Disember 1965.

15 CUEPACS Annual Report 1964-1965, $7^{\text {th }}$ Congress Convention, 19, 20 and 21 November 1965, at Selangor Girl Guides’ Association Hall, Kuala Lumpur, hlm. 65.

16 Ibid.

17 Berita Harian, 25 Mei 1964, hlm. 1.

18 Ibid.

19 Ibid.

${ }^{20}$ CUEPACS Annual Report 1964-1965, 7th Congress Convention, 19, 20 and 21 November 1965, at Selangor Girl Guides’ Association Hall, Kuala Lumpur, hlm. 65.

${ }^{21}$ Ibid.

${ }^{22}$ Ibid.

${ }^{23}$ Ibid.

${ }^{24}$ Ibid.

25 Ibid.

26 Eastern Sun, 12 Julai 1968.

27 "Suara CUEPACS Julai 1968” dalam jurnal Kongres Kesatuan Pekerja-pekerja dalam Perkhidmatan Awam, Kuala Lumpur: Penerbit Congress of Unions of Employees in the Public and Civil Services,1968, hlm. 9. 
28 Ibid., hlm. 10.

29 "Suara CUEPACS Julai 1968” dalam jurnal Kongres Kesatuan Pekerja-pekerja dalam Perkhidmatan Awam, Kuala Lumpur: Penerbit Congress of Unions of Employees in the Public and Civil Services, 1968, hlm. 10.

30 Menurut Tunku Abdul Rahman iaitu Perdana Menteri Malaysia menyatakan bahawa kebimbangan terhadap ancaman tindakan mogok beberapa kesatuan sekerja dalam Majlis Whiley sekiranya kerajaan tidak menyelesaikan tuntutan mereka menyebabkan keutamaan diberikan untuk meluluskan Peraturan 1965, iaitu Prohibition of Strike and Certain Proscribed Industrial Action dan Arbitration in the Essential Service. Parliamentary Debate, Dewan Ra'ayat, Official Report, 29 November 1965, Kuala Lumpur: Penchetak Kerajaan, 1967, hlm. 4021.

${ }^{31}$ Utusan Malaysia, 8 Julai 1968.

32 Utusan Malaysia, 1 Julai 1968.

33 Yang Dipertua kesatuan tersebut, iaitu Encik Mohamed bin Yunus menyeru supaya pemimpin-pemimpin CUEPACS mengkaji semula keputusan mogok yang dianggapnya dibuat secara terburu-buru sedangkan kerajaan masih membuka pintu rundingan. Berita Harian, 11 Julai 1968.

34 Sebenarnya, sudah terdapat permintaan awal supaya Tun Abdul Razak mengadakan pertemuan secara tidak rasmi dengan wakil-wakil CUEPACS yang dibuat oleh Pekerja Perkhidmatan Teknik Malaya untuk menyelesaikan ancaman mogok. Utusan Malaysia, 1 Julai 1968.

35 "Suara CUEPACS Julai 1968" dalam jurnal Kongres Kesatuan Pekerja-pekerja dalam Perkhidmatan Awam, hlm. 10.

36 Ibid.

${ }^{37}$ Ibid.

38 Ibid.

39 "Suara CUEPACS Jun 1969" dalam jurnal Kongres Kesatuan Pekerja-pekerja dalam Perkhidmatan Awam, Kuala Lumpur: Penerbit Congress of Unions of Employees in the Public and Civil Services, 1969, hlm. 2.

40 Ibid.

41 “Suara CUEPACS Januari 1970” dalam jurnal Kongres Kesatuan Pekerja-pekerja dalam Perkhidmatan Awam, Kuala Lumpur: Penerbit Congress of Unions of Employees in the Public and Civil Services, 1970, hlm. 2.

42 Ibid.

${ }^{43}$ Tujuan penubuhan Jawatankuasa Khas Gaji di Persekutuan Malaya Benham, 1950 adalah seperti berikut:

a. Untuk menimbangkan dan mengesyorkan tangga gaji yang lebih adil kepada semua kakitangan awam yang berkhidmat dalam pelbagai bahagian dan jabatan dalam Perkhidmatan Awam Persekutuan Tanah Melayu.

b. Untuk membuat syor yang lebih khusus mengenai tangga gaji yang lebih sesuai kepada pekerja wanita.

Penjelasan lanjut sila rujuk Report of the Special Committee on Salaries in the Federation of Malaya, September 1950, Kuala Lumpur: Government Printer, 1950, hlm. 1.

44 Jumlah anggota wanita dalam sektor awam adalah terhad dan hanya terdapat seorang wanita dalam Malayan Civil Service (MCS) yang bertugas sebagai pegawai kontrak selama tiga tahun. Di samping itu, pegawai wanita dalam perkhidmatan awam yang sudah mendirikan rumah tangga diminta meletakkan jawatan dan kemudian dilantik semula 
sebagai pegawai sementara. Walaupun sebilangan besar pegawai wanita ditempatkan dalam profesion perguruan dan jururawat yang mempunyai kelayakan akademik sama dan menjalankan tugas yang sama seperti lelaki tetapi gaji yang dibayar adalah lebih rendah berbanding lelaki. Penjelasan lanjut sila rujuk F. R. Bhupalan. 2006. "Indefatigable Proponent of Women's Right and Justice”, dalam Prabhakaran Nair, Prince Among Men, Kuala Lumpur: Arkib Negara Malaysia, hlm. 261.

45 Parliamentary Debate, Dewan Ra'ayat, Official Report, Persekutuan Tanah Melayu: Pencetak Kerajaan, 1963, hlm. 1566.

46 Kongress Kesatuan Pekerja-pekerja di dalam Perkhidmatan Awam, Laporan untuk 1968-1970, Persidangan Perwakilan yang ke-11, bertarikh 18,19 dan 20 Disember 1970 bertempat di Dewan Persatuan Pemandu Puteri, Kuala Lumpur, hlm. 124.

47 Ibid.

48 Ibid., hlm 125-126.

${ }^{49}$ Gaji permulaan bagi kerani lelaki adalah $\$ 137.50$ dan kerani wanita $\$ 122.50$. Berita Harian, 12 April 1958, hlm. 2.

50 Perbahathan Parlimen, Dewan Negara yang Kedua, Penggal Kelima, Penyata Rasmi, 7 Jun 1968, Kuala Lumpur: Penchetak Kerajaan, 1969, hlm. 59-60.

${ }^{51}$ Ibid.

\section{RUJUKAN}

Berita Harian, 12 April 1958.

Berita Harian, 25 Mei 1964.

Berita Harian, 11 Julai 1968.

Bhupalan. F. R. (2006). Indefatigable proponent of women's right and justice.

Dlm. Prabhakaran Nair, Prince Among Men. Kuala Lumpur: Arkib Negara Malaysia.

CUEPACS Annual Report 1964-1965, 7th Congress Convention, 19, 20 and 21

November 1965, at Selangor Girl Guides’ Association Hall, Kuala Lumpur. Eastern Sun, 12 Julai 1968.

http://www.cuepacs.my/index.php/cuepacs-23/sejarah-cuepacs.html, 7 Mac 2018. Kongress Kesatuan Pekerja-pekerja di dalam Perkhidmatan Awam, Laporan untuk 1968-1970, Persidangan Perwakilan yang ke-11, bertarikh 18, 19 dan 20 Disember 1970 bertempat di Dewan Persatuan Pemandu Puteri, Kuala Lumpur.

Parliamentary Debate, Dewan Ra'ayat, Official Report. (1963). Persekutuan Tanah Melayu: Penchetak Kerajaan.

Parliamentary Debate, Dewan Ra'ayat, Official Report. (1967). 29 November 1965. Kuala Lumpur: Penchetak Kerajaan.

Pekeliling Perkhidmatan Bil. 5 Tahun 1969. Kuala Lumpur, 5 Ogos 1969.

Perbahathan Parlimen, Dewan Negara yang Kedua, Penggal Kelima, Penyata Rasmi, 7 Jun 1968. (1969). Kuala Lumpur: Penchetak Kerajaan.

Report of Mission from the ILO, The Trade Union Situation in the Federal of Malaya, Geneva, 1962. 
Report of the Secial Committee on Salaries in the Federation of Malaya, September 1950, (1950). Kuala Lumpur: Government Printer.

Ramlah Adam. (2009). Biografi Tunku Abdul Rahman Putra. Kuala Lumpur: Dewan Bahasa dan Pustaka.

Rohana Ariffin. (1997). Women and trade unions in Peninsular Malaysia with special reference to MTUC and CUEPACS. Pulau Pinang: Penerbit Universiti Sains Malaysia.

Straits Times, 31 Ogos 1957.

"Suara CUEPACS Julai 1968" dalam jurnal Kongres Kesatuan Pekerja-pekerja dalam Perkhidmatan Awam, Kuala Lumpur: Penerbit Congress of Unions of Employees in the Public and Civil Services, 1968.

"Suara CUEPACS Jun 1969" dalam jurnal Kongres Kesatuan Pekerja-pekerja dalam Perkhidmatan Awam, Kuala Lumpur: Penerbit Congress of Unions of Employees in the Public and Civil Services, 1969.

“Suara CUEPACS Januari 1970” dalam jurnal Kongres Kesatuan Pekerja-pekerja dalam Perkhidmatan Awam, Kuala Lumpur: Penerbit Congress of Unions of Employees in the Public and Civil Services, 1970.

Utusan Melayu, 1 September 1957.

Utusan Malaysia, 1 Julai 1968.

Utusan Malaysia, 8 Julai 1968.

Yap Sui Fok. (1988/89). CUEPACS, Keanjalan Upah dan Perundingan Kolektif dalam Perkhidmatan Awam Malaysia, Kertas Projek/LI, Fakulti Ekonomi, Universiti Kebangsaan Malaysia. 